http://kitaibelia.unideb.hu/

ISSN 2064-4507 (Online) • ISSN 1219-9672 (Print)

(C) Department of Botany, University of Debrecen, Hungary

23 (1): 107-108.; 2018

DOI: $10.17542 /$ kit.23.107

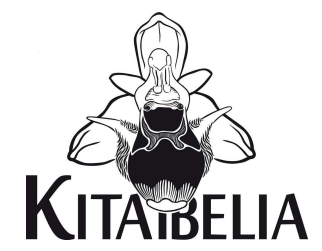

\title{
Útmutató a szerzőkhöz
}

\begin{abstract}
A lap irányultsága
A KITAIBELIA botanikai-természetvédelmi folyóirat florisztikai, növényföldrajzi, taxonómiai, nevezéktani, társulástani, ökológiai, természetvédelmi botanikai, tudománytörténeti témájú eredeti dolgozatokat közöl. A terjedelmesebb cikkek a Lektorált közlemények sorában, a rövidebbek az Apró közlemények című rovatban jelennek meg. Frissen megjelent és széleskörü érdeklődésre számot tartó botanikai művek ismertetésére az Irodalmi figyelő rovatban biztosítunk lehetőséget.
\end{abstract}

\section{Közlemények benyújtása és megjelenése}

A kéziratokat elektronikusan a szerkesztőség címére (kitaibelia@unideb.hu) kérjük benyújtani. A szerkesztő a formai vagy tartalmi elvárásoknak nem megfelelő kéziratokat visszautasíthatja vagy javításra visszaküldheti. Az elvárásoknak megfelelő kéziratokat két független bíráló tekinti át. A lektorok személyére a szerzők javaslatot tehetnek, ügyelve az összeférhetetlenség elkerülésére (közvetlen munkatárs, rendszeres társszerző, témavezető stb. nem ajánlott). A kézirat javítását a lektori vélemény útmutatásai szerint a szerzők végzik. A szükséges javításokat és pótlásokat követően a szerzők újraküldik a dolgozatot a szerkesztőnek, aki (esetleg a lektorok véleményének ismételt kikérésével) dönt a dolgozat befogadásáról. Elfogadást követően a szerkesztett és nyelvileg ellenőrzött kéziratot a szerzők megjelenés előtt kézhez kapják jóváhagyásra. Lapunk évente két füzettel jelenik meg elektronikusan (http://kitaibelia.unideb.hu/) és nyomtatásban is. A kéziratok benyújtási határideje az adott évi első számba március 15., a második számba augusztus 20. Felhívjuk szerzőink figyelmét, hogy terjedelmesebb anyagok (ábrák, táblázatok, cönológiai felvételek stb.) megjelenítésére elektronikus-melléklet formájában is lehetőség van.

\section{Formai követelmények}

A kéziratokat szerkeszthető formában (.doc, .docx vagy .txt kiterjesztésben) várjuk. A szöveg Times New Roman betûtípussal, 12-es betűmérettel készüljön. A taxonnevek dőlt, az irodalmi hivatkozásokban szereplő szerzői nevek KISKAPITÁLIS, az auktornevek, herbáriumi gyűjtők és szüntaxonok nevei szabályos, a fejezetcímek félkövér (bold) szedésűek legyenek. A benyújtott kéziratnak tartalmaznia kell a következőket: a cikk címe (max. 100 karakter); a cikk angol címe; a cikk rövid címe (max. 60 karakter); a szerző(k) neve; a szerzők elérhetősége (munkahelyi postai cím); a kapcsolattartó szerző drótposta címe; magyar és angol nyelvű összefoglaló max. 200-200 szó terjedelemben; 4-6 a címben nem szereplő, releváns kulcsszó magyarul és angolul; a cikk szövege; az ábrák és táblázatok címei és feliratai magyarul és angolul. A dolgo- 
zatok ajánlott tagolása: Bevezetés és célkitűzés, Anyag és módszer, Eredmények, Eredmények értékelése, Összefoglalás, Köszönetnyilvánítás, Irodalomjegyzék. Ettől a tagolástól indokolt esetben el lehet térni.

Nyomtatásban szürkeárnyalatos, míg az online közzétett dokumentumokban színes ábrák megjelenítésére (is) van lehetőség. Az ábrák és táblázatok a kézirat végén szerepeljenek, szövegközi hivatkozásaiknak megfelelő sorrendben. Az ábrákat .jpg vagy .tif kiterjesztésben, 600 dpi felbontással külön is kérjük megküldeni. A növényábrák (rajz, herbáriumi példány) mellett tüntessék fel a méretvonalakat, térképeken a léptéket vagy méretarányt.

A tudományos nevek első cikkbeli említésekor fel kell tüntetni az auktort is (kivétel: társulástani tabellákban, lelőhelyek fajlistáiban szereplő fajnevek). Az auktornevek, faj- és szüntaxon-nevek használatát illetően valamely széles körben használt forrást ajánlott követni, e műveket a kéziratban fel kell tüntetni.

Benyújtás előtt kérjük ellenőrizzék, hogy minden szövegközi hivatkozásnak megfelelő irodalmi tétel szerepel-e az irodalomjegyzékben, és vice versa. Folyóiratok címét rövidítés nélkül kérjük megadni. Kérjük, hogy a DOI-val (Digital Object Identifier) rendelkező művek esetén az azonosítókat is tüntessék fel az irodalomjegyzékben. Az irodalmi források leggyakoribb típusai az irodalomjegyzékben az alábbiak szerint legyenek tagolva és formázva:

könyv

KIRÁLY G. (szerk.) (2009): Új magyar füvészkönyv. Magyarország hajtásos növényei. Határozókulcsok. Aggteleki Nemzeti Park Igazgatóság, Jósvafó.

\section{könyvrészlet}

BALOGH L., DANCZA I. \& KiRÁLY G. (2004): A magyarországi neofitonok időszerű jegyzéke, és besorolásuk inváziós szempontból. - In: MiHÁLY B. \& BotTA-DuKÁT Z. (szerk.), Biológiai inváziók Magyarországon: Özönnövények. A KvVM Természetvédelmi Hivatalának tanulmánykötetei 9, TermészetBúVÁR Alapítvány Kiadó, Budapest, pp. 61-92.

folyóiratcikk

NIKLFELD H. (1971): Bericht über die Kartierung der Flora Mitteleuropas. - Taxon 20: 545-571. DOI doi.org/10.2307/1218258

kézirat

PILLICH F., ifj. (1930): Simontornya és környéke flórája. - Kézirat, Simontornya, 74 pp.

Florisztikai cikkek enumerációjában kötelező megadni a közép-európai flóratérképezés (CEU/KEF) hálórendszerében (NIKLFELD 1971) a lelőhelyet fedő kvadrát azonosítóját [XXXX.Y] formátumban. Florisztikai adatok közül legalább a jelentősebbeket, illetve a bonyolult taxonómiájú növényeket ajánlott valamely nagyobb hazai közgyűjteményben (például MTM Növénytár, Carpato-Pannonicum gyűjtemény; DE Növénytani Tanszék, Soó Rezső Herbárium) elhelyezett herbáriumi példánnyal dokumentálni.

A Pótlások Magyarország edényes növényfajainak elterjedési atlaszához sorozathoz az adatokat táblázatos formában várjuk (minimálisan a következő attribútumokkal: Fajnév; Település; KEF-kód; Dátum; Adatközlő neve; Státusz - pl. adventív, 1990 utáni őshonos stb.).

Honlapunk vonatkozó oldalán (http://kitaibelia.unideb.hu/?instruction) részletesebb útmutató olvasható. Minden további kérdésben kérje a szerkesztőség tanácsát. 